\title{
Birth weight and hospital admission before the age of 2 years
}

\author{
Lesley Mutch, Hazel Ashurst, Alison Macfarlane
}

\begin{abstract}
Admission rates to hospital of children born weighing $1500 \mathrm{~g}$ or less were compared with those born with birth weights over $1500 \mathrm{~g}$ in a retrospective analysis of routinely collected data from the Oxford Record Linkage Study. The children were born in the three five year periods 1968-72, 1974-8, and 1979-83 to women resident in Oxfordshire and West Berkshire. The main measures of the study were survival rates to 28 days after birth and hospital admissions of survivors up to the age of two years.
\end{abstract}

Among babies weighing $1500 \mathrm{~g}$ or less, neonatal survival rates rose from 350.2 per 1000 total births in $1968-72$ to 577.4 per 1000 among births in 1979-83. Over the same period, the proportion of children admitted to hospital at least once before the age of 2 years rose from 218.6 per 1000 survivors to 444.4 per 1000 . In the children with birth weights over $1500 \mathrm{~g}$, survival rates rose from 985.5 to 995.9 per 1000 births and hospital admission rates rose from $98 \cdot 2$ to 144.4 per 1000 survivors over the same time period.

Although very low birthweight children did not contribute significantly to total hospital bed occupancy, because their numbers were small in relation to the total number of children in the population, their contribution increased between the five year periods 196872 and 1979-83. It should therefore be continuously monitored using routine systems.

Over the past 20 years, the survival rates of very immature babies have increased dramatically, As a result, many children who would have died in the past are now surviving and living healthy normal lives. Nevertheless, there has been speculation about the consequences of this increased survival in terms of overall levels of morbidity among the survivors. There is already evidence that the prevalence of cerebral palsy among low birthweight children is rising ${ }^{2}$ and also of an increase in less dramatic forms of morbidity among these vulnerable babies. ${ }^{3-5}$

Ideally, routine child health surveillance systems should be able to provide the information that is required to monitor the evolving situation in the light of continuing increases in the survival rates. Unfortunately, despite considerable investment of resources in planning and piloting these systems in the UK, those in use in England are not yet able to generate the standard information that is required on a national basis.

Five years ago, we reported the results of an investigation which made use of the Oxford Record Linkage Study to examine trends in admission rates among very low birthweight and heavier children born in the two five year periods 1968-72 and 1974-8 in Oxfordshire and West Berkshire, to women living in those areas. ${ }^{4}$ Our analysis demonstrated a rise in the absolute and relative risks of hospital admission among very low birthweight children. The increase in absolute risk was largely accounted for by increased admission rates of babies with respiratory infections, structural defects, such as hernia, trauma and poisoning, and miscellaneous other conditions. In this paper we report an extension of our earlier analysis to the children born during the period 1979-83, during which there was a further increase in survival rates among low birthweight babies.

\section{Methods}

A detailed account of our study methods has already been published. ${ }^{4}$ The study used the Oxford Record Linkage Study to obtain routinely collected data. ${ }^{6}$ The database includes records of all births, deaths, and hospital admissions occurring in Oxfordshire and West Berkshire. Records relating to all babies weighing $1500 \mathrm{~g}$ or less at birth, together with those for random samples of heavier babies, were extracted from the maternity file. The analysis was restricted to babies born to women who both lived and delivered in the study area during the five year periods 1968-72, 1974-8, and 1979-83. In each of these quinquennia, approximately $6 \%$ of births to residents of Oxfordshire and West Berkshire took place outside the study area. These were not included in the analyses. In addition, it was not possible to trace admissions of children to hospitals outside the Oxford region. Copies of death certificates were obtained for all children who died under the age of 2 years.

An episode of hospitalisation was defined as an inpatient stay or a day case admission occurring after the initial discharge from hospital after birth, and at any time between 28 days and 2 years. Data on hospital discharges were extracted manually from listings of records of all discharges of children admitted before the age of 2 years, by matching on names and dates of birth. The data extracted included age at admission, duration of stay, and the diagnoses recorded on discharge from hospital. The hospitalisation rate was calculated as the number of discharges per 1000 children surviving 28 days after live birth. The diagnoses recorded on discharge from hospital were grouped into 11 cate- 
Table 1 Changes between 1968-72 and 1979-83 in the numbers of deaths and mortality rates among babies born to women living and delivering in Oxfordshire or West Berkshire, by birth weight

\begin{tabular}{|c|c|c|c|c|c|c|c|c|}
\hline & \multicolumn{4}{|c|}{ Birth weight of $1500 \mathrm{~g}$ or less } & \multicolumn{4}{|c|}{ Birth weight over $1500 \mathrm{~g}$} \\
\hline & $1968-72$ & $1974-8$ & $1979-83$ & $\begin{array}{l}\% \text { Change in rate } \\
\text { between } 1968-72 \\
\text { and } 1979-83\end{array}$ & $1968-72$ & $1974-8$ & $1979-83$ & $\begin{array}{l}\% \text { Change in rate } \\
\text { between } 1968-72 \\
\text { and } 1979-83\end{array}$ \\
\hline $\begin{array}{l}\text { Total births } \\
\text { Live births } \\
\text { Stillbirths* }\end{array}$ & $\begin{array}{l}614 \\
523 \\
191\end{array}$ & $\begin{array}{r}379 \\
295 \\
84\end{array}$ & $\begin{array}{r}433 \\
354 \\
79\end{array}$ & & $\begin{array}{r}67863 \\
67393 \\
470\end{array}$ & $\begin{array}{r}52751 \\
52468 \\
283\end{array}$ & $\begin{array}{r}56039 \\
55894 \\
145\end{array}$ & \\
\hline (2) & $(311 \cdot 1)$ & $(221 \cdot 6)$ & $(182 \cdot 4)$ & -41 & $(6 \cdot 9)$ & $(5 \cdot 4)$ & $(2 \cdot 6)$ & -62 \\
\hline Early neonatal deaths $\dagger$ & 199 & $\begin{array}{r}99 \\
\end{array}$ & 86 & th & 423 & 260 & 169 & \\
\hline Late neonatal deaths $\dagger$ & $(4 / 0)$ & $\begin{array}{c}(3350) \\
15\end{array}$ & $\begin{array}{c}(242 \cdot 9) \\
18\end{array}$ & 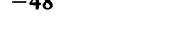 & $\begin{array}{r}(6 \cdot 3) \\
90\end{array}$ & $\begin{array}{r}(5 \cdot 0) \\
76\end{array}$ & $\begin{array}{r}(3 \cdot 0) \\
60\end{array}$ & -52 \\
\hline & $(21 \cdot 2)$ & $(50 \cdot 5)$ & $(50 \cdot 8)$ & +140 & $(1 \cdot 3)$ & $(1 \cdot 4)$ & $(1 \cdot 1)$ & -15 \\
\hline Postneonatal deaths $†$ & $\begin{array}{r}8 \\
(18.9)\end{array}$ & $\begin{array}{c}12 \\
(40.6)\end{array}$ & $\begin{array}{r}4 \\
(11 \cdot 3)\end{array}$ & -40 & $\begin{array}{r}327 \\
(4 \cdot 9)\end{array}$ & $\begin{array}{r}217 \\
(4 \cdot 1)\end{array}$ & $\begin{array}{r}218 \\
(3.9)\end{array}$ & -20 \\
\hline Deaths $366-729$ days $\dagger$ & 0 & & & & 72 & 40 & 23 & \\
\hline Live born babies & $\begin{array}{l}(0 \cdot 0) \\
215\end{array}$ & $\begin{array}{c}(3.4) \\
181\end{array}$ & $\begin{array}{c}(2 \cdot 8) \\
250\end{array}$ & & $\begin{array}{r}(1 \cdot 1) \\
66880\end{array}$ & $\begin{array}{r}(0 \cdot 8) \\
52132\end{array}$ & $\begin{array}{r}(0 \cdot 4) \\
55665\end{array}$ & -64 \\
\hline surviving to 28 days $f$ & $(350 \cdot 2)$ & $(477 \cdot 6)$ & $(577 \cdot 4)$ & +65 & $(985 \cdot 5)$ & $(988 \cdot 3)$ & $(995 \cdot 9)$ & +1 \\
\hline
\end{tabular}

${ }^{*}$ Rates per 1000 total births shown in parentheses.

tRates per 1000 live births shown in parentheses.

gories based on codes from the eighth and ninth revision of the International Classification of Diseases. ${ }^{78}$ As up to four diagnostic codes could be recorded for each episode, rates were based on the number of times a diagnostic grouping was mentioned.

It is possible that there were changes over time in the predisposition among paediatricians to admit children to hospital, their use of diagnostic labels, and the way that these were recorded. In an attempt to control for this, the admission rates of the very low birthweight babies were compared with those of the samples of bigger babies by estimating the odds ratios and their $\mathbf{9 5 \%}$ confidence intervals. ${ }^{9}$

\section{Results \\ CHILDREN BORN WEIGHING 1500 G OR LESS}

Table 1 shows that the chance that a baby born weighing $1500 \mathrm{~g}$ or less in the years $1979-83$ was $65 \%$ more likely to survive until the end of the neonatal period than a baby born in the period 1968-72. In contrast, table 2 shows that over the same period the rate of admission to hospital before the age of 2 years doubled, from 218.6 to 444.4 per 1000 survivors. As noted in our earlier paper the increased rate of admission between 1968-72 and 1974-8 was accounted for by an increase in the rate of admission of babies with infections, structural defects, trauma and poisoning, and miscellaneous 'other' conditions, among which, asthma predominated. ${ }^{4}$ Table 3 shows that, with the exception of structural defects other than hernias, the same categories, and in particular infections and miscellaneous other conditions, contributed to the more substantial rise between 1974-8 and 1979-83 in the overall rate of hospitalisation. In addition, there were statistically significant rises in the admission rates for nutritional disorders, convulsions, and 'perinatal' conditions, which included bronchopulmonary dysplasia, the sequelae of necrotising enterocolitis, and haemolytic disease.

CHILDREN BORN WEIGHING MORE THAN $1500 \mathrm{G}$

Table 1 shows that between 1968-72 and 197983 , there was a $1 \%$ increase in survival to 28 days after live birth among children born weighing over $1500 \mathrm{~g}$. The overall rate of hospitalisation among such children born in the period 1974-8, shown in table 2, was somewhat lower than for similar children born during 1968-72. This change was largely explained by reduced rates of admission for congenital malformations, structural defects and other anomalies, and convulsions, shown in table 3. For children born from 1979-83, however, the overall rate of hospitalisation was 143.3 per 1000 survivors, substantially higher than the rate of 89.4 for children born in the period 1974-8. This rise reflected increases in all but two of the diagnostic categories, but was mainly seen in increased mentions of diagnoses of infections, malformations, convulsions, perinatal and other conditions, notably non-specific symptoms and signs.

Table 2 Numbers and rates of readmission by period of birth and by birth weight

\begin{tabular}{|c|c|c|c|c|c|c|c|c|c|}
\hline & \multicolumn{3}{|c|}{ Birth weight of $1500 \mathrm{~g}$ or less } & \multicolumn{3}{|c|}{$\begin{array}{l}\text { Sample of children with } \\
\text { birth weight over } 1500 \mathrm{~g}\end{array}$} & \multicolumn{3}{|c|}{$\begin{array}{l}\text { Odds ratios associated with being very low birth weight } \\
(95 \% \text { confidence interval })\end{array}$} \\
\hline & $1968-72$ & $1974-8$ & $1979-83$ & $1968-72$ & $1974-8$ & $1979-83$ & $1968-72$ & $1974-8$ & $1979-83$ \\
\hline $\begin{array}{l}\text { Total births } \\
\text { No of liveborn } \\
\text { babies surviving } \\
\text { up to } 28 \text { days* }\end{array}$ & $\begin{array}{r}614 \\
215 \\
(350 \cdot 2)\end{array}$ & $\begin{array}{r}379 \\
181 \\
(477 \cdot 6)\end{array}$ & $\begin{array}{r}433 \\
250 \\
(577 \cdot 4)\end{array}$ & $\begin{array}{r}1202 \\
1181 \\
(982 \cdot 5)\end{array}$ & $\begin{array}{r}742 \\
738 \\
(994 \cdot 6)\end{array}$ & $\begin{array}{r}924 \\
921 \\
(998 \cdot 7)\end{array}$ & $\begin{array}{l}0.0096 \\
(0.0060 \text { to } 0.0152)\end{array}$ & $\begin{array}{l}0.0090 \\
(0.0018 \text { to } 0.0135)\end{array}$ & $\begin{array}{l}0.0044 \\
(0.0014 \text { to } 0.0140)\end{array}$ \\
\hline \multicolumn{10}{|c|}{ No of children rehospitalised $\dagger$} \\
\hline $\begin{array}{l}\text { Unce } \\
\text { Twice } \\
\text { Three or more } \\
\text { times }\end{array}$ & $\begin{array}{r}47 \\
(218 \cdot 6) \\
21 \\
(97 \cdot 7) \\
12 \\
(55 \cdot 8)\end{array}$ & $\begin{array}{r}49 \\
(270 \cdot 7) \\
12 \\
(66 \cdot 3) \\
12 \\
(66 \cdot 3)\end{array}$ & $\begin{array}{r}(444 \cdot 4) \\
34 \\
(136 \cdot 0) \\
24 \\
(96 \cdot 0)\end{array}$ & $\begin{array}{r}116 \\
(98 \cdot 2) \\
20 \\
(16 \cdot 9) \\
5 \\
(4 \cdot 2)\end{array}$ & $\begin{array}{r}66 \\
(89 \cdot 4) \\
12 \\
(26 \cdot 3) \\
2 \\
(2 \cdot 7)\end{array}$ & $\begin{array}{r}(143 \cdot 3) \\
23 \\
(25 \cdot 0) \\
7 \\
(7 \cdot 6)\end{array}$ & $\begin{array}{l}(1 \cdot 76 \text { to } 3 \cdot 74) \\
6 \cdot 28 \\
(3 \cdot 34 \text { to } 11 \cdot 8) \\
13 \cdot 3 \\
(4 \cdot 62 \text { to } 38 \cdot 0)\end{array}$ & $\begin{array}{l}3 \cdot 78 \\
(2 \cdot 50 \text { to } 5 \cdot 72) \\
4 \cdot 30 \\
(1 \cdot 90 \text { to } 9 \cdot 73) \\
26 \cdot 1 \\
(5 \cdot 79 \text { to } 11 \cdot 8)\end{array}$ & $\begin{array}{l}4 \cdot 77 \\
(3 \cdot 50 \text { to } 6 \cdot 51) \\
6.15 \\
(3.55 \text { to } 10 \cdot 6) \\
13 \cdot 87 \\
(5.9 \text { to } 32 \cdot 59)\end{array}$ \\
\hline
\end{tabular}

* Rate per 1000 live births shown in parentheses.

tRate per 1000 babies surviving to 28 days shown in parentheses. 
COMPARISONS BETWEEN TRENDS FOR CHILDREN WITH VERY LOW AND HIGHER BIRTH WEIGHTS

Table 4 shows that the overall odds ratio for rehospitalisation among low birthweight children compared with those born with higher birth

Table 3 Numbers of mentions of diagnostic categories on discharge records by birth weight (rates per 1000 survivors)

\begin{tabular}{|c|c|c|c|c|c|c|}
\hline & \multicolumn{3}{|c|}{ Birth weight of $1500 \mathrm{~g}$ or less } & \multicolumn{3}{|c|}{ Birth weight over $1500 \mathrm{~g}$} \\
\hline & $1968-72$ & $1974-8$ & $1979-83$ & $1968-72$ & $1974-8$ & $1979-83$ \\
\hline $\begin{array}{l}\text { Neonatal survivors } \\
\text { No of children readmitted at }\end{array}$ & 215 & 181 & 250 & 1181 & 738 & 921 \\
\hline $\begin{array}{l}\text { least once } \\
\text { Diagnostic category }\end{array}$ & 47 & 49 & 111 & 116 & 66 & 132 \\
\hline Malformation & $\begin{array}{r}20 \\
(93 \cdot 0)\end{array}$ & $\begin{array}{r}12 \\
(66 \cdot 3)\end{array}$ & $\begin{array}{r}21 \\
(84 \cdot 0)\end{array}$ & $\begin{array}{r}21 \\
(17 \cdot 8)\end{array}$ & $\begin{array}{r}7 \\
(9 \cdot 5)\end{array}$ & $\begin{array}{r}31 \\
(33 \cdot 7)\end{array}$ \\
\hline All structural defects & $\begin{array}{r}17 \\
(79 \cdot 1)\end{array}$ & $\begin{array}{r}23 \\
(127 \cdot 1)\end{array}$ & $\begin{array}{r}29 \\
(116.0)\end{array}$ & $\begin{array}{r}19 \\
(16 \cdot 1)\end{array}$ & $\begin{array}{r}5 \\
(6 \cdot 8)\end{array}$ & $\begin{array}{r}10 \\
(10.9)\end{array}$ \\
\hline Hernia & $\begin{array}{r}14 \\
(65 \cdot 1)\end{array}$ & $\begin{array}{r}18 \\
(99 \cdot 4)\end{array}$ & $\begin{array}{r}27 \\
(108 \cdot 0)\end{array}$ & $\begin{array}{r}13 \\
(11 \cdot 0)\end{array}$ & $\begin{array}{r}2 \\
(2 \cdot 7)\end{array}$ & $\begin{array}{r}6 \\
(6 \cdot 5)\end{array}$ \\
\hline Other anomalies & $\begin{array}{r}9 \\
(41 \cdot 9)\end{array}$ & $\begin{array}{r}5 \\
(27 \cdot 6)\end{array}$ & $\begin{array}{r}12 \\
(48.0)\end{array}$ & $\begin{array}{r}11 \\
(9 \cdot 3)\end{array}$ & $\begin{array}{r}1 \\
(1 \cdot 4)\end{array}$ & $\begin{array}{r}4 \\
(4 \cdot 3)\end{array}$ \\
\hline All infections & $\begin{array}{r}21 \\
(97 \cdot 6)\end{array}$ & $\begin{array}{r}28 \\
(154 \cdot 6)\end{array}$ & $\begin{array}{r}98 \\
(392 \cdot 0)\end{array}$ & $\begin{array}{r}41 \\
(34 \cdot 7)\end{array}$ & $\begin{array}{r}29 \\
(39 \cdot 3)\end{array}$ & $\begin{array}{r}89 \\
(96 \cdot 6)\end{array}$ \\
\hline Upper respiratory infection & $\begin{array}{r}1 \\
(4 \cdot 7)\end{array}$ & $\begin{array}{r}4 \\
(22 \cdot 1)\end{array}$ & $\begin{array}{r}7 \\
(28.0)\end{array}$ & $\begin{array}{r}3 \\
(2 \cdot 5)\end{array}$ & $\begin{array}{r}1 \\
(1 \cdot 3)\end{array}$ & $\begin{array}{r}4 \\
(4 \cdot 3)\end{array}$ \\
\hline Chest infection & $\begin{array}{r}7 \\
(32 \cdot 6)\end{array}$ & $\begin{array}{r}12 \\
(66 \cdot 2)\end{array}$ & $\begin{array}{r}37 \\
(148 \cdot 0)\end{array}$ & $\begin{array}{r}15 \\
(12 \cdot 7)\end{array}$ & $\begin{array}{r}9 \\
(12 \cdot 2)\end{array}$ & $\begin{array}{r}17 \\
(18 \cdot 5)\end{array}$ \\
\hline Trauma/poisoning & $\begin{array}{c}2 \\
(9 \cdot 3)\end{array}$ & $\begin{array}{r}4 \\
(22 \cdot 1)\end{array}$ & $\begin{array}{r}10 \\
(40.0)\end{array}$ & $\begin{array}{r}32 \\
(27 \cdot 1)\end{array}$ & $\begin{array}{r}21 \\
(28 \cdot 5)\end{array}$ & $\begin{array}{r}24 \\
(26 \cdot 1)\end{array}$ \\
\hline Nutritional deficiency/disorders & $\begin{array}{r}10 \\
(46 \cdot 5)\end{array}$ & $\begin{array}{r}6 \\
(33 \cdot 1)\end{array}$ & $\begin{array}{r}30 \\
(120 \cdot 0)\end{array}$ & $\begin{array}{r}4 \\
(3 \cdot 4)\end{array}$ & $\begin{array}{r}8 \\
(10 \cdot 8)\end{array}$ & $\begin{array}{r}6 \\
(6 \cdot 5)\end{array}$ \\
\hline Convulsions & $\begin{array}{r}5 \\
(23 \cdot 3)\end{array}$ & $\begin{array}{r}3 \\
(16 \cdot 6)\end{array}$ & $\begin{array}{r}14 \\
(56.0)\end{array}$ & $\begin{array}{r}11 \\
(9 \cdot 3)\end{array}$ & $\begin{array}{r}3 \\
(4 \cdot 1)\end{array}$ & $\begin{array}{r}19 \\
(20 \cdot 6)\end{array}$ \\
\hline Perinatal conditions & $\begin{array}{r}4 \\
(18 \cdot 6)\end{array}$ & $\begin{array}{r}2 \\
(11 \cdot 0)\end{array}$ & $\begin{array}{r}27 \\
(108 \cdot 0)\end{array}$ & $\begin{array}{r}2 \\
(1 \cdot 7)\end{array}$ & $(1 \cdot 4)$ & $\begin{array}{r}8 \\
(8 \cdot 7)\end{array}$ \\
\hline Other/or not known & $\begin{array}{r}15 \\
(69 \cdot 8)\end{array}$ & $\begin{array}{r}21 \\
(116 \cdot 0)\end{array}$ & $\begin{array}{r}64 \\
(256 \cdot 0)\end{array}$ & $\begin{array}{r}22 \\
(18 \cdot 6)\end{array}$ & $\begin{array}{r}14 \\
(19 \cdot 0)\end{array}$ & $\begin{array}{r}35 \\
(38 \cdot 0)\end{array}$ \\
\hline
\end{tabular}

Table 4 Odds ratios and 95\% confidence intervals of readmission for very low birthweight children compared with heavier children for each diagnostic category

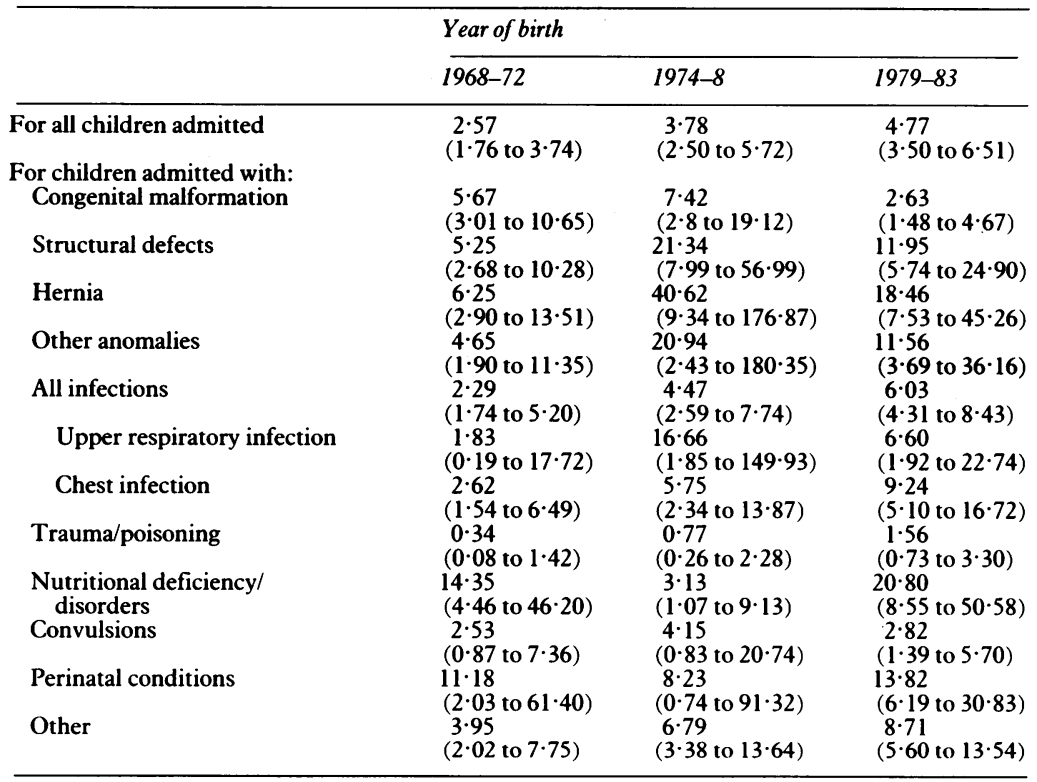

Table 5 Changes over time in the number of episodes and length of stay by birth weight

\begin{tabular}{llll}
\hline & \multicolumn{2}{l}{ Year of birth } & \\
\cline { 2 - 4 } & $1968-72$ & $1974-8$ & $1979-83$ \\
\hline Average No of episodes/child & $1 \cdot 8$ & $1 \cdot 8$ & $1 \cdot 9$ \\
$\leqslant 1500 \mathrm{~g}$ & $1 \cdot 2$ & $1 \cdot 2$ & $1 \cdot 2$ \\
$>1500 \mathrm{~g}$ & $4 \cdot 8$ & $3 \cdot 5$ & $4 \cdot 2$ \\
Median length of stay/episode (days) & 3.6 & $2 \cdot 8$ & $2 \cdot 1$ \\
$\leqslant 1500 \mathrm{~g}$ & $7 \cdot 6$ & 4.9 & $6 \cdot 1$ \\
$>1500 \mathrm{~g}$ & $4 \cdot 5$ & $3 \cdot 1$ & $2 \cdot 3$ \\
Median length of stay/child (days) & & & \\
\hline $1500 \mathrm{~g}$ & & & \\
\hline
\end{tabular}

Table 6 The contribution of very low birthweight children to total hospital inpatient stays by children aged between 28 days and 2 years

\begin{tabular}{llll}
\hline & \multicolumn{3}{l}{ Year of birth } \\
\cline { 2 - 4 } & $1968-72$ & $1974-8$ & $1979-83$ \\
\hline Birth weight 1500 g or less as: & & 1.0 & 1.4 \\
\% Of all children admitted & 0.9 & 1.0 & 2.0 \\
\% Of all admission episodes & 0.7 & 1.0 & 4.4 \\
\% Of all days spent in hospital & 1.5 & 1.9 & \\
\hline
\end{tabular}

weights rose from 2.57 for those born in 1968 72 to 3.78 for those born in $1974-8$ and 4.77 for those born in 1979-83. Among births in 1979_ 83 , the diagnostic categories for which the odds ratios were highest, were structural defects and other anomalies, hernia, perinatal conditions, nutritional deficiency/disorders, and chest infections. Only in the case of nutritional and deficiency disorders was there a greatly increased risk of admission in 1979-83 compared with 1974-8 but this was still no greater than would be expected by chance. Within this category the most common diagnoses were 'failure to thrive' and 'feeding problems'.

For children born weighing $1500 \mathrm{~g}$ or less, table 5 shows no clear trends over time in the average number of episodes of rehospitalisation per survivor, or in the median length of stay, whether expressed per episode or per child. Among the children with higher birth weights, the average number of episodes of hospitalisation remained constant at $1 \cdot 2$ over the whole of the period studied. In contrast to the lack of any clear trend among children with very low birth weights, the median length of stay, per episode and per child, fell progressively. As a consequence of this, the contribution of children with very low birth weights to the overall numbers of inpatient stays has increased over the three periods as table 6 shows.

\section{Discussion}

Our results confirm that surviving very low birthweight babies are a vulnerable group of children who experience substantially higher levels of subsequent hospitalisation than heavier babies. Others have reported readmission rates of between 32 and $53 \%$ in the first year of life $^{31014}$ against a background of admission rates of between 10 and $15 \%$ for all children. ${ }^{14} 15$ Our findings are consistent with this range.

Between the five year periods 1968-72 and $1979-83$ the rate of hospitalisation of very low birthweight babies who survived the first 28 days of life doubled, while their neonatal mortality fell by $65 \%$. The rate of hospital admission among heavier survivors fell between the first two cohorts, but then rose in the cohort born in 1979-83. This latter finding is consistent with the results of a cross sectional study covering a much larger proportion of the population of the Oxford region but restricted to the two years $1975^{\circ}$ and $1985 .^{16}$ That study reported an increase in admissions of all children aged 0-14 years. This was mainly accounted for by a rise in admissions to medical as opposed to surgical specialities.

The contribution of very low birthweight 
babies to the total use of hospital beds by children between the ages of 28 days and two years is small, as table $\mathbf{6}$ shows. It is increasing, however, and there is a possibility that this increased bed use may also continue beyond the second year of life. In 1979-83, 34\% of the lighter babies were readmitted in the first year of life, compared with $9 \%$ of the heavier babies. In the second year of life, $10 \%$ of the smaller children but only $5 \%$ of the heavier group were readmitted for the first time. Data from the 1946 national cohort suggested that the higher rate of admission for very small babies did not persist after the second year of life. ${ }^{17}$ More recent data from the Scottish low birthweight study (L Mutch, in preparation) shows a continued high rate of hospital admission between 2 and 4.5 years of age. By the age of 2 years, $23 \%$ of children who weighed under $1500 \mathrm{~g}$ at birth had been readmitted, but by 4.5 years this figure had reached $65 \%$.

The contribution of children born weighing under $1500 \mathrm{~g}$ to all hospital admissions rose by 1.5 times from $0.9 \%$ in $1968-72$ to $1.4 \%$ in 1979-83. This increase was lower than the 2.9-fold rise in their contribution to the total number of days spent in hospital.

There are several possible explanations for the increased rates of readmission among the cohorts of children born during the early 1980s. It has been suggested that the increase in the rate of hospital admission may reflect greater pressure from parents or general practitioners for inpatient care, or 'lower thresholds for admission resulting, in part, from the increased availability of beds because of the diminishing lengths of stay'. ${ }^{16}$ Although our study was designed to take account of changes in the threshold for admission within each of the paired cohorts, the data do not allow us to investigate changes in the threshold over time. It seems to us that this issue could only be addressed in studies that explore reasons for the decision to refer a child to hospital, and the admitting doctor's decision to admit the child. This cannot be ascertained retrospectively from routinely collected data.

Another possible contribution to the trends might be that doctors are referring and admitting to hospital children suffering from conditions that were not previously thought to be amenable to treatment. This notion does not receive support from the observed pattern of diagnostic categories, among which infections of the upper and lower respiratory tract dominated.

Lastly, the rising readmission rates may partly reflect a real increase in the prevalence of illness in these children. Even if this is so, it seems unlikely that child health has deteriorated to the extent implied by the rise in hospitalisation rates, particularly among the heavier group of children. As far as the very low birthweight children are concerned, however, this increase would be consistent with trends seen in other relevant data. Although the increasing survival of very low birthweight babies has been accompanied by an increase in the number of neurologically intact children in the population, the number of these children who have cerebral palsy has also been increasing. ${ }^{18}$ Furthermore it has been reported that the chances of readmission are likely to be higher among children with a handicapping condition. ${ }^{14}$

Our analyses are set against the background of increased rates of admission for all age groups in the Oxford region ${ }^{19}$ and the debate about how these should be interpreted. For all children, it has been shown that although the number of admissions has increased, the total time spent in hospital has decreased. ${ }^{20}$ Table 5 shows that whereas this is true for the heavier children in our study, there is no clear trend for the very low birthweight children.

Like ours, the studies of all admissions were based on data collected routinely and brought together as part of the Oxford Record Linkage Study. In theory, population based district information systems which district health authorities have been told to implement by April $11993^{21}$ should be able to provide similar information. Meanwhile, it has been shown that linkage of routine Körner data about successive hospital admissions is technically feasible, ${ }^{22} 23$ although use of readmission rates as an outcome measure of hospital inpatient care has been challenged. ${ }^{24}$ Linkage between maternity data and subsequent hospital admission of babies poses an added problem, however, as does the incompleteness of Körner maternity data, ${ }^{25}$ but the importance of overcoming these difficulties cannot be overemphasised.

\section{CONCLUSIONS}

Although very low birthweight children did not contribute significantly to total hospital bed occupancy because their numbers were small in relation to the total number of children in the population, their contribution increased between the five year periods 1968-72 and 1979-83. Future patterns should therefore be monitored continuously using routine systems.

We should like to thank Myfanwy Griffiths, Margaret Godden, and Tony Peeke at the Oxford Record Linkage Study who kindly provided the raw data, and Dr Michael Goldacre, the director, for acs. Colleagues at the National Perinatal Epidemiology or access. Colleagues at the National Perinatal Epidemiology Unit have commented on successive drafts and have, as always, given helpful advice. Colin Pritchard of the Public Health Research Unit gave useful advice on a later draft. Grateful thanks are due to Gaye Bell, Pam Hughes, Lyn Pilcher, and Caroline Caldicott for help in preparing the manuscrip.

Lesley Mutch was supported by a project grant from the Department of Health and Social Security, as it then was. The National Perinatal Epidemiology Unit is funded by the Department of Health, as are Myfanwy Griffiths and Margaret Godden.

1 Hagberg B, Hagberg G, Olow I, Wendt I. The changing agberg B, Hagberg G, Olow 1, Wendt 1 . The changing panorama of CP
1989;78:283-90.

2 Anonymous. Cerebral palsy, intrapartum care, and a shot in the foot [Editorial]. Lancet 1989;ii:1251-2.

3 Hack M, Caron B, Rivers A, Fanaroff AA. The very low birthweight infant: the broader spectrum of morbidity during infancy and early childhood. Developmental and Behavioural Pediatrics 1983;4:243-9.

4 Mutch L, Newdick M, Lodwick A, Chalmers I. Secular changes in rehospitalisation of very low birthweight infants. Pediatrics 1986;79:164-71.

5 Chan KN, Elliman A, Bryan E, Silverman M. Respiratory symptoms in children of low birthweight. Arch Dis Child 1989;64:1294-304.

6 Acheson ED. Medical record linkage. Nuffield Provincial Hospitals Trust. Oxford: Oxford University Press, 1967.

7 World Health Organisation. International classification of diseases. 8th revision. Geneva: WHO, 1967

World Health Organisation. International classification of diseases. 9th revision. Geneva: WHO, 1977

Miettinen OS Estimability and estimation in case-referent studies. Am 7 Epidemiol 1976;103:226-35. 
10 McCormick MC, Shapiro S, Starfield B. Rehospitalisation in the first year of life for high risk survivors. Pediatrics 1980 66:991-9.

11 Morgan MEI. Late morbidity of very low birthweight infants. $B M \mathcal{F}$ 1985;291:175-76.

12 Greenough A, Roberton NRC. Effect of a regional neonatal unit on a general paediatric ward. $B M \mathcal{J} 1985 ; 291: 175-6$.

13 Skeoch H, McIlwaine G, Skeoch C, Rosenberg K, Turner T. Very low birthweight survivors: illness and readmission to hospital in the first 15 months of life. $B M \mathcal{J}$ 1987;295: hospital

14 van Zeben van der Aa DM, Verloove-Vanhorick SP, Brand $R$, Ruys JH. The use of health service in the first 2 years of life in a nationwide cohort of very preterm and/or very low life in a nationwide cohort of very preterm and/or very low
birthweight infants in the Netherlands: rehospitalisation birthweight infants in the Netherlands: rehospitalisation and outpa $11-26$.

15 Hack M, De Monterice RN, Merkatz IR, Jones P, Fanaroff A. Rehospitalisation of the very low birthweight infant. Am f Dis Child 1981;135:263-6.

16 Hill AM. Trends in paediatric medical admissions. $B M \mathcal{F}$ 1989;298:1479-83.
17 Douglas JWB, Mogford C. Health of premature children from birth to four years. BMF 1953;i:748-54.

18 Pharoah POD, Cooke T, Cooke RWI, Rosenbloom L. Birthweight specific trends in cerebral palsy. Arch Dis Child 1990;65:602-6.

19 Goldacre MJ, Simmons H, Henderson J, Gill LE. Trends in episode based and person based rates of admissions to hospital in the Oxford record linkage study area. BMF 1988;296:583-4.

20 Henderson J, Goldacre $M$, Griffiths $M$. Time spent in hospital by children: trends in the Oxford record linkage hospital by children: trends in the Oxford

21 Department of Health. Framework for information systems: the next steps. London: HMSO, 1990 .

22 Chambers M, Clarke A. Measuring readmission rates. BMF 1990;301:1134-6.

23 Greener B. Readmission rates: an indicator of quality of care? British fournal of Healthcare Computing 1989 Dec: 12-3.

24 Clarke A. Are readmissions avoidable? BMF 1990;301 1336-8.

25 Parliamentary written answer. House of Commons Official Report (Hansard). 1991 June 21;193:col 324

Pertussis (2): acellular vaccines and household contact

'Oh, come on', I said. 'How can they do it?' I said. 'What parents are going to agree to it? You can't conduct a placebo controlled trial of pertussis vaccine. Well, can you?' Yes, you can; and the reason why is mentioned as a casual passing comment, after five columns of print, by Jan Storsaeter and colleagues (American Fournal of Diseases of Children 1992;146:167-72). Routine pertussis immunisation was stopped in Sweden in 1979 so no child in the trial was denied something the rest of the population was getting. If only they'd said that in their introduction they could have saved me a lot of adrenaline.

Nearly 4000 children aged 6 to 11 months were included in the trial. In each group of eight children three were given a two component Japanese acellular pertussis vaccine (JNIH-6), three were given a monocomponent acellular vaccine (JNIH-7), and two were given placebo injections. Each child received two injections two months apart. Previous studies using whole cell vaccines have shown rates of protection after household contact of 50 to $60 \%$ in Britain and $70-90 \%$ in the United States, the higher protection in the United States being possibly a consequence of the extended five dose course used there.

On follow up for at least $\mathbf{1 4}$ months after the second injection those who received placebo were more likely than those who were given a vaccine to suffer from pertussis. For the JNIH-6 vaccine the difference was highly significant $(p<0.001)$ but for the JNIH7 vaccine it was less so $(p=0 \cdot 09)$. After househould contact culture confirmed pertussis occurred in 13 of $16(81 \%)$ in the placebo group, seven of $26(27 \%)$ in the JNIH-7 groups, and 10 of 19 $(53 \%)$ in the JNIH-6 group.

The estimated vaccine efficacy after household exposure for culture confirmed pertussis was $35 \%$ for the JNIH-6 vaccine and $67 \%$ for the JNIH-7. For clinical pertussis with 21 days or more of paroxysmal cough the estimated efficacies were 58 and $82 \%$ respectively. These differences did not reach statistical significance.

Blood samples for serological tests were obtained from children and adults after household exposure but no association was found between serum concentrations of antibodies against pertussis toxin or filamentous haemagglutin and the degree of protection. The authors conclude that the two component JNIH-6 vaccine is more protective against community exposure but there is no significant difference between the vaccines as regards protection after household exposure. 